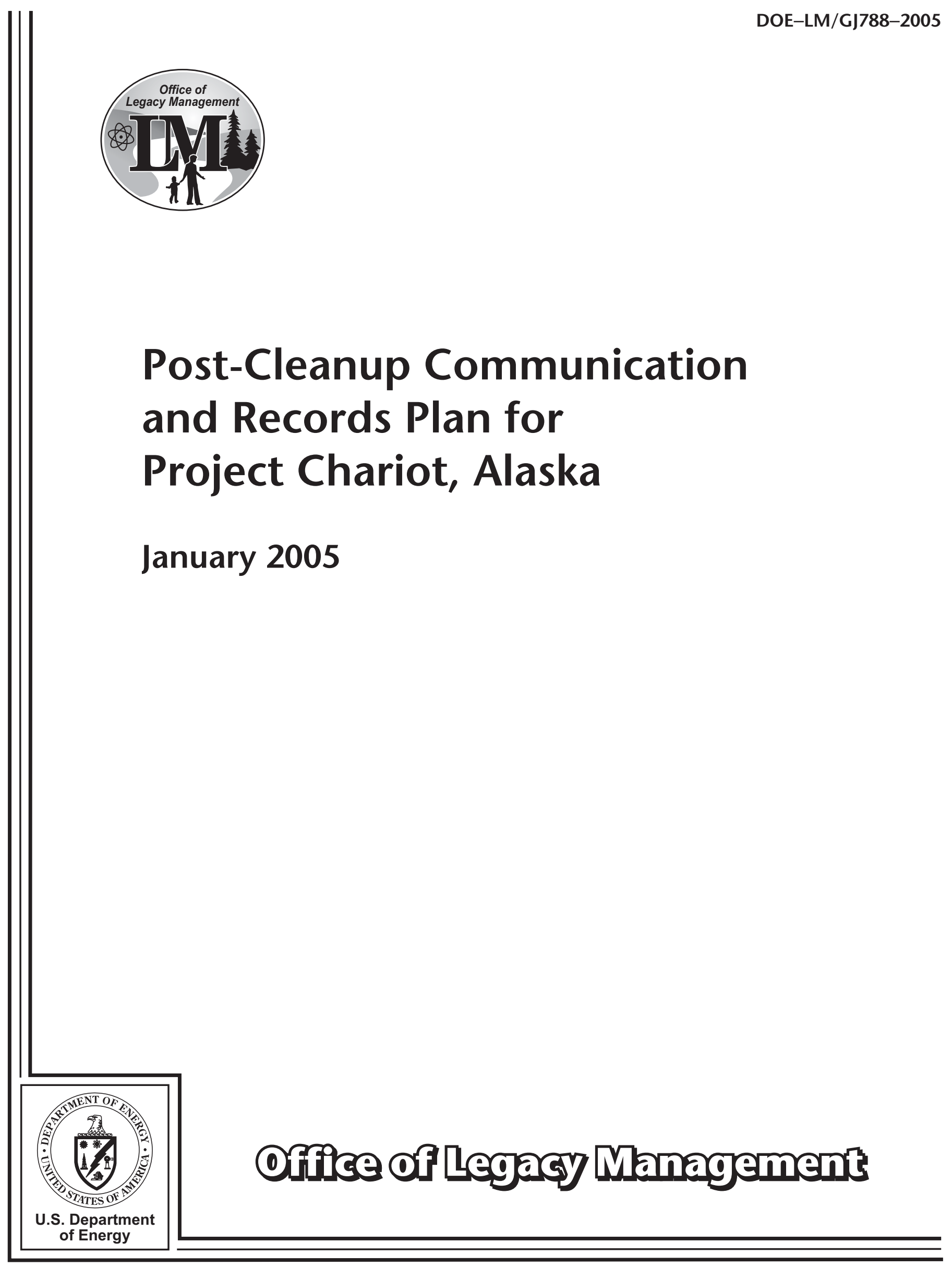




\section{Post-Cleanup Communication and Records Plan for Project Chariot, Alaska}

January 2005 


\section{Contents}

(1)

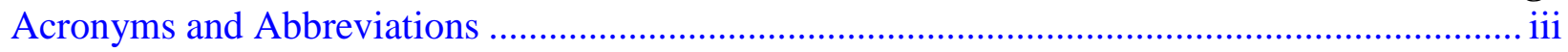

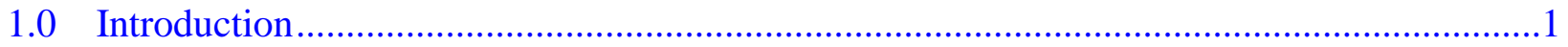

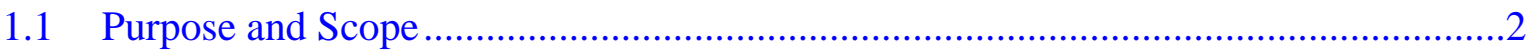

1.2 Post-Closure Legal and Regulatory Requirements ....................................................2

1.3 Stewardship Overview ……………………………...........................................

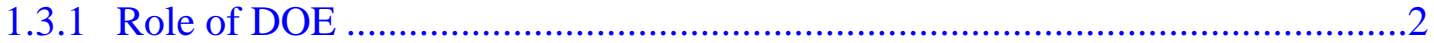

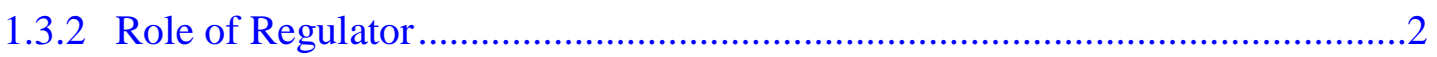

1.3.3 Role of Local Governments and Other Agencies ................................................

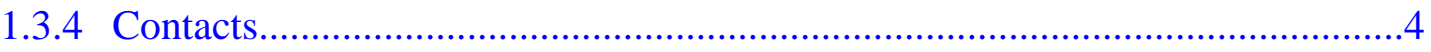

2.0 Project Chariot Site Background and Status ...................................................................

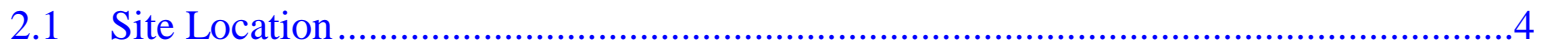

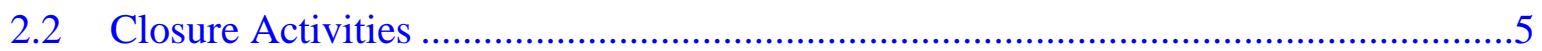

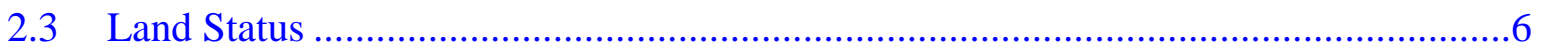

2.4 Access to the Project Chariot Area...........................................................................

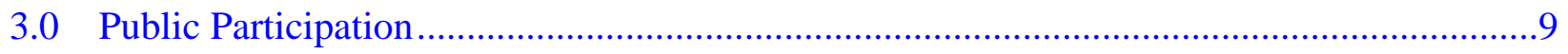

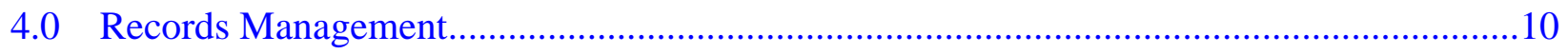

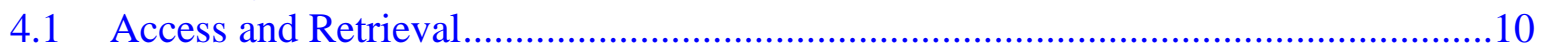

4.2 Disposition of the Record Collection .....................................................................10

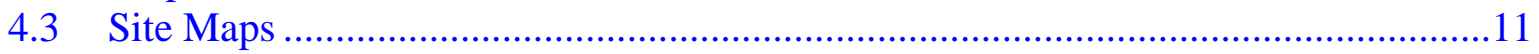

$4.4 \quad$ Site Record Drawings and Maps ……………….................................................11

4.5 Site Photographs and Other Special Media ……………........................................11

4.6 Site Aerial Photographs ......................................................................................11

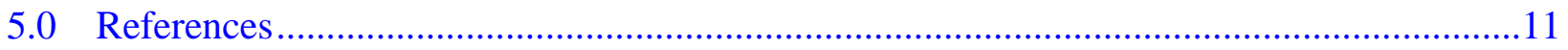

Figures

Figure 1-1. Cape Thompson and Project Chariot Location (DOE 1994) ..................................... 1

Figure 1-2. Land Ownership of the Cape Thompson Subunit of the Alaska Maritime National Wildlife Refuge (USFWS 1993a) with Detail of the Ogotoruk Valley (USGS 1960) showing the former Location of Project Chariot.

Figure 2-1. Project Chariot Sites Layout (DOE 1994). The disposal mound is in the center of the figure. The percolation test plot (\#116) and the stream sediment test (\#117) are north-northwest of the mound. ............................................................................ 6

Figure 2-2. Portion of BLM-Alaska Record Title Plot Showing Navy-Administered Land (shaded in blue) and Patented Native American Allotment (cross hatch) at the Mouth of Ogotoruk Creek.

\section{Appendices}

Appendix A, Alaska Department of Environmental Conservation Closure Approval Letters ………………………………………........................ A-1

Appendix B, List of Recipients of this Plan ........................................................................ 


\section{Acronyms and Abbreviations}

\begin{tabular}{|c|c|}
\hline AEC & U.S. Atomic Energy Commission \\
\hline AMNWR & Alaska Maritime National Wildlife Refuge \\
\hline BLM & [U.S. Department of Interior] Bureau of Land Management \\
\hline CFR & Code of Federal Regulations \\
\hline DOE & U.S. Department of Energy \\
\hline DOE-NV & U.S. Department of Energy Nevada Operations Office \\
\hline DOE-EM & U.S. Department of Energy Environmental Management Program \\
\hline $\mathrm{ft}$ & feet \\
\hline $\mathrm{ft}^{3}$ & cubic feet \\
\hline FUDS & $\begin{array}{l}\text { [Defense Environmental Restoration Program for] Formerly Used } \\
\text { Defense Sites }\end{array}$ \\
\hline FY & fiscal year \\
\hline $\mathrm{km}$ & kilometer \\
\hline $\mathrm{km}^{2}$ & square kilometers \\
\hline DOE-LM & U.S. Department of Energy Office of Legacy Management \\
\hline $\mathrm{m}$ & meters \\
\hline $\mathrm{m}^{3}$ & cubic meters \\
\hline $\mathrm{mCi}$ & millicuries \\
\hline NNSA/NSO EM & $\begin{array}{l}\text { U.S. Department of Energy, National Nuclear Security } \\
\text { Administration/Nevada Site Office Environmental } \\
\text { Management Program }\end{array}$ \\
\hline PLO & Public Land Order \\
\hline SLUP & Special Land Use Permit \\
\hline URL & Uniform Resource Locator on the World Wide Web \\
\hline USFWS & U.S. Department of the Interior, Fish and Wildlife Service \\
\hline USGS & U.S. Geological Survey \\
\hline yd & yard \\
\hline $\mathrm{yd}^{3}$ & cubic yards \\
\hline
\end{tabular}




\subsection{Introduction}

The Project Chariot Site resides in a remote and isolated area in the Cape Thompson region of northwest Alaska (Figure 1-1). The Project Chariot Site was a proposed test location for the U.S. Atomic Energy Commission (AEC) Plowshare Program in 1958.

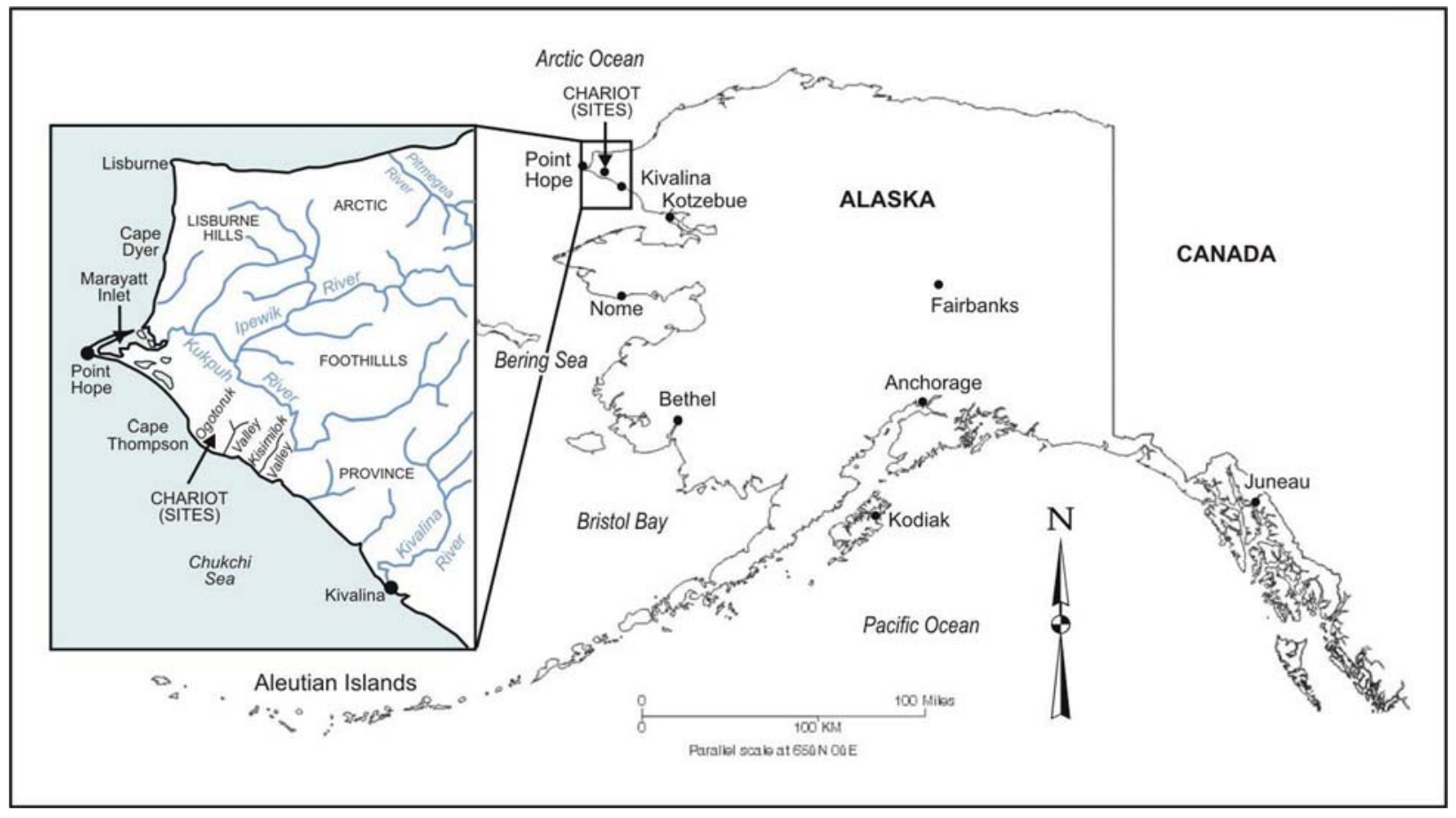

Figure 1-1. Cape Thompson and Project Chariot Location (DOE 1994)

In 1962, the United States Geological Survey (USGS) conducted environmental studies using less than $30 \mathrm{mCi}$ of short-lived mixed fission products. The location of the studies was about 0.75 mile $(1.2 \mathrm{~km})$ north of the Project Chariot Site base camp. Radioactive material was spread over the 12 test plots: 10 were used for overland transport tracer tests, one for a sediment transport experiment, and one for an 18-hour percolation test. The 11 test plots constituted an area less than 0.9 percent of an acre. At the conclusion of the August 1962 tracer test, USGS scraped the ground surface of the test plots and the percolation test location. The scraped soil and vegetation were mixed with native soil, deposited in a mound on two of the plots, and covered with $4 \mathrm{ft}$ (1.22 $\mathrm{m}$ ) of uncontaminated soil (DOE 1993).

Later in 1962, nuclear-excavation engineering studies were terminated and the proposed nuclear excavation for a harbor was abandoned. No nuclear explosive devices were ever brought onto the Project Chariot Site.

In 1992, a University of Alaska researcher discovered old letters from the USGS and told the U.S. Army Corps of Engineers and the media that radioisotopes were buried on site without the proper permits. In response to public concern, State of Alaska officials and the U.S. Department of Energy (DOE), successor to AEC, agreed in 1992 to remove the material. A surface radiation survey measured on the mound was within the range of the local background radiation. Slightly 
elevated readings were measured at 3.5-foot $(1.1 \mathrm{~m}$ below the surface $)$ in a hole drilled into the mound.

Cleanup was completed by October $1993 ; 162 \mathrm{yd}^{3}\left(123.9 \mathrm{~m}^{3}\right)$ of slightly contaminated debris was shipped to the DOE Nevada Test Site for disposal.

Appendix A provides copies of the August 23 and August 26, 1993, letters from the State of Alaska that reviewed the environmental sampling results, confirmed the tracer-test site was clean, and approved closure of the site. The Project Chariot, Site Assessment and Remediation Action Final Report (DOE 1994) describes the cleanup actions and sampling results that demonstrate the site is clean for unrestricted use.

The DOE no longer has an active interest in the tracer test site or the Project Chariot Site and is currently not the land administrator for either of these sites (see Section 2.3).

\subsection{Purpose and Scope}

The purpose of this document is to describe the post-completion actions for the Project Chariot tracer-test site. Because the site is "clean closed" and approved for unrestricted use, actions are limited to:

- Managing and maintaining official government records for the site.

- Providing public access to the regulatory documentation.

- Maintaining contact lists of appropriate federal and state officials that can be contacted for inquiries.

- Responding to inquiries about the site.

\subsection{Post-Closure Legal and Regulatory Requirements}

The site is approved for unrestricted use (see Appendix A). The remaining requirement is for the Federal Government to maintain records that demonstrate the sites are clean. The records are maintained in accordance with federal records requirements and the National Archives and Records Administration.

\subsection{Stewardship Overview}

\subsubsection{Role of DOE}

The DOE Office of Legacy Management (LM) is responsible for managing and maintaining official records for the site, including those records that designate the site is clean.

\subsubsection{Role of Regulator}

The regulator concurred that the tracer-test site was "clean closed" in 1993 (Appendix A). There is no ongoing role for the regulator. The regulator may be called upon if needed to help DOE respond to inquiries.

Post-Cleanup Communication and Records Plan for Project Chariot, Alaska 


\subsubsection{Role of Local Governments and Other Agencies}

The former tracer-test site (Figure 1-2) is on federal land withdrawn by the U.S. Navy (BLM 1974). If site access is necessary, also contact the holder of the patented Native American allotment (BLM 1990). The Federal Government holds access easements on the allotment.

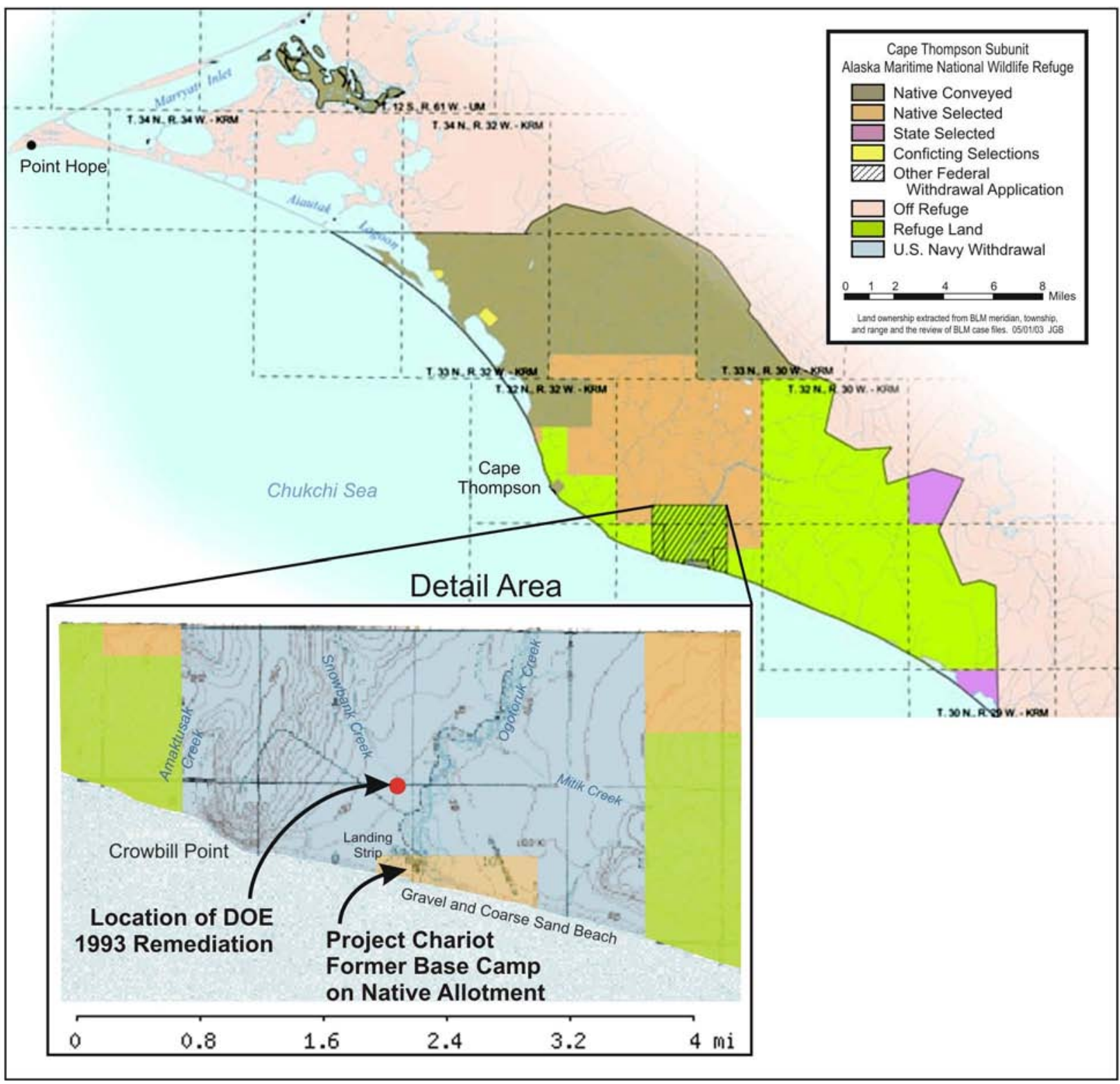

Figure 1-2. Land Ownership of the Cape Thompson Subunit of the Alaska Maritime National Wildlife Refuge (USFWS 1993a) with Detail of the Ogotoruk Valley (USGS 1960) showing the former Location of Project Chariot. 


\subsubsection{Contacts}

\begin{tabular}{|l|l|l|}
\hline \multicolumn{1}{|c|}{ Contacts } & \multicolumn{1}{|c|}{ Address } & \multicolumn{1}{c|}{ Telephone/URL or Email } \\
\hline $\begin{array}{l}\text { Bureau of Land Management } \\
\text { Northern Field Office }\end{array}$ & $\begin{array}{l}1150 \text { University Avenue } \\
\text { Fairbanks, AK 99709-3844 }\end{array}$ & $\begin{array}{l}\text { 907-474-2200 } \\
\text { http://aurora.ak.blm.gov/ }\end{array}$ \\
\hline $\begin{array}{l}\text { Alaska Maritime National } \\
\text { Wildlife Refuge }\end{array}$ & 95 Sterling Highway, & $\begin{array}{l}907-235-6546 \\
\text { alaskamaritime@fws.gov }\end{array}$ \\
U.S. Fish \& Wildlife Service & Suite 1 & Homer, AK 99603 \\
\hline U.S. Navy & $100177^{\text {th }}$ Avenue, NE & 360-396-0908 \\
Naval Facilities Engineering & Poulsbo, WA 98370 & www.navy.mil \\
Command & & Menu trail: \\
Engineering Field Activity, & & Navy Organization \\
Northwest (EFANW) & & The Shore Establishment \\
Real Estate Group & & Naval Facilities \\
& & Engineering Command \\
& & [press OK] \\
& & Organization \\
& & NAVFAC Atlantic \\
& & Northwest (EFANW) \\
\hline
\end{tabular}

The University of Alaska Fairbanks and the Fairbanks North Slope Borough Public Library maintain public reading rooms that includes copies of documents pertaining to Project Chariot.

\begin{tabular}{|c|c|c|}
\hline Public Reading Rooms & Address & Telephone/URL \\
\hline $\begin{array}{l}\text { University of Alaska, Fairbanks } \\
\text { Elmer E. Rasmuson Library }\end{array}$ & $\begin{array}{l}310 \text { Tanana Drive } \\
\text { Fairbanks, AK 99775-6817 }\end{array}$ & $\begin{array}{l}\text { 907-474-7211 } \\
\text { http://www.uaf.edu/library/ }\end{array}$ \\
\hline $\begin{array}{l}\text { Fairbanks North Star Borough } \\
\text { Public Library and Regional } \\
\text { Center }\end{array}$ & $\begin{array}{l}1215 \text { Cowles Street } \\
\text { Fairbanks, AK } 99701\end{array}$ & $\begin{array}{l}\text { 907-459-1020 } \\
\text { http://library.fnsb.lib.ak.us/ }\end{array}$ \\
\hline
\end{tabular}

\subsection{Project Chariot Site Background and Status}

\subsection{Site Location}

Portions of this section were taken from the Project Chariot: Site Transition Plan (DOE 2004) and some of this material was excerpted from Project Chariot: Nuclear Legacy of Cape Thompson (Vandegraft 1993). The latter is quoted or indented without quotes herein. Parts of this material have been condensed and modified. This acknowledgment is the citation for much of this section including Figure 1-1.

The Project Chariot sites are located in the Cape Thompson region of northwest Alaska (Figure 1-1). 


\subsection{Closure Activities}

Two cleanup events were conducted: one by the U.S. Navy on the Project Chariot Site and one by DOE on the nearby tracer test study site.

In 1963, AEC relinquished Project Chariot Site administration to the U.S. Navy for the support of its Arctic Research Laboratory. When the U.S. Navy ceased operation of this project, the Project Chariot Site was transferred to the Bureau of Land Management (BLM) in 1970 (DOE 1994).

The U.S. Navy used a variety of structures at the base camp area at the Project Chariot Site. The Navy was not involved in any activities on the land used for the 1962 tracer test. The facilities that were the responsibility of U.S. Navy operations were remediated during the 1990 to 1992 period under the U.S. Department of Defense, Defense Environmental Restoration Program for Formerly Used Defense Sites (FUDS). The remediation conducted under the FUDS program did not address any of the radiological contamination from the Project Chariot tracer test (DOE 1994).

The DOE Secretary accepted responsibility for removal of the waste from the Project Chariot tracer-test site because DOE's predecessor, AEC, created the waste. DOE Nevada Operations Office (DOE-NV) performed an initial site assessment of the Project Chariot tracer-test site in late October 1992.

Between December 1992 and June 1993, DOE developed the Project Chariot: 1962 Tracer Study Site Assessment and Remedial Action Plan (DOE 1993). Local public meetings with stakeholders were held in Barrow, Kivalina, Kotzebue, and Point Hope, Alaska. The plan was finalized.

In July and August 1993, DOE conducted a site assessment and performed site remediation. The remediation consisted of scraping off the mound and a 3-plot cluster (plots 105, 106, and 107) left by the USGS. The approximate surface area of the mound was $59 \mathrm{ft}$ by $56 \mathrm{ft}(18 \mathrm{~m}$ by $17 \mathrm{~m})$ (DOE 1993). The 3-plot cluster surface area was $19.6 \mathrm{ft}$ by $16.4 \mathrm{ft}$ (6 m by $5 \mathrm{~m}$ ) (DOE 1994). Approximately $150 \mathrm{yd}^{3}\left(114.7 \mathrm{~m}^{3}\right)$ were removed from the mound area and approximately $12 \mathrm{yd}^{3}\left(9.2 \mathrm{~m}^{3}\right)$ were removed from the 3-plot cluster. The mound and 3-plot cluster are shown on Figure 2.1 along with approximate locations for the test plots. Plot number 117 was the site of the sediment tracer test.

Approximately $162 \mathrm{yd}^{3}\left(123.9 \mathrm{~m}^{3}\right)$ of soil, vegetation, and water in the soil matrix were placed in 41 B-25 shipping containers and shipped, along with 13 others, to the Nevada Test Site for disposal (DOE 1994). The State of Alaska approved the closure and issued two acceptance letters (see Appendix A). The site was clean closed. DOE has completed its remediation actions at the tracer-test site. 


\subsection{Land Status}

The Project Chariot tracer-test site (see Figure 2-1) is located on land withdrawn and administered by the U.S. Navy (BLM 1974). The Chukchi Sea, the patented Native American allotment, and the Alaska Maritime National Wildlife Refuge (AMNWR) bound it.

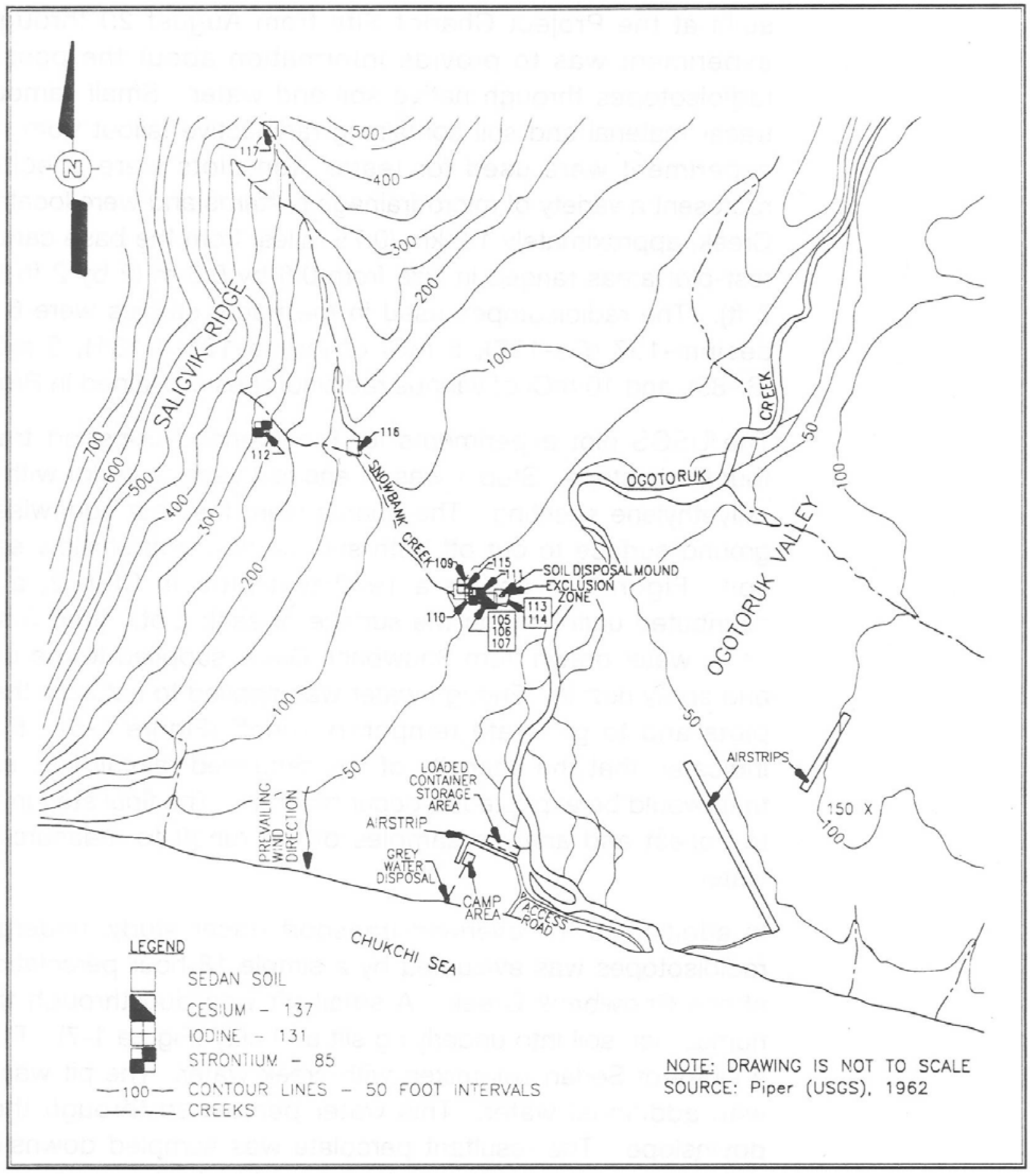

Figure 2-1. Project Chariot Sites Layout (DOE 1994). The disposal mound is in the center of the figure. The percolation test plot (\#116) and the stream sediment test (\#117) are north-northwest of the mound. 
The U.S. Department of the Interior, Fish and Wildlife Service (USFWS) administers AMNWR (Federal Register 1980). The Project Chariot base camp and airstrips are on a patented Native American allotment near the tracer-test remediation site. The allotment holder's land was used during the remediation to stage equipment and personnel and to land planes. An agreement was concluded with the holder of the Native American allotment to allow use for these purposes during the remediation (Fiore 1992).

No restrictions are in place as a result of DOE remediation activities because the tracer-test site has been clean closed.

The mound was located north of the mouth of Ogotoruk Creek in the Kateel River Meridian, T 31 N., R 31 W., just west of the intersection of Sections 3, 4, 9, and 10. The base camp and its landing strip are approximately located at the boundary between Sections 9 and 10 (see Figure 2-2) near the discharge of Ogotoruk Creek into the Chukchi Sea.

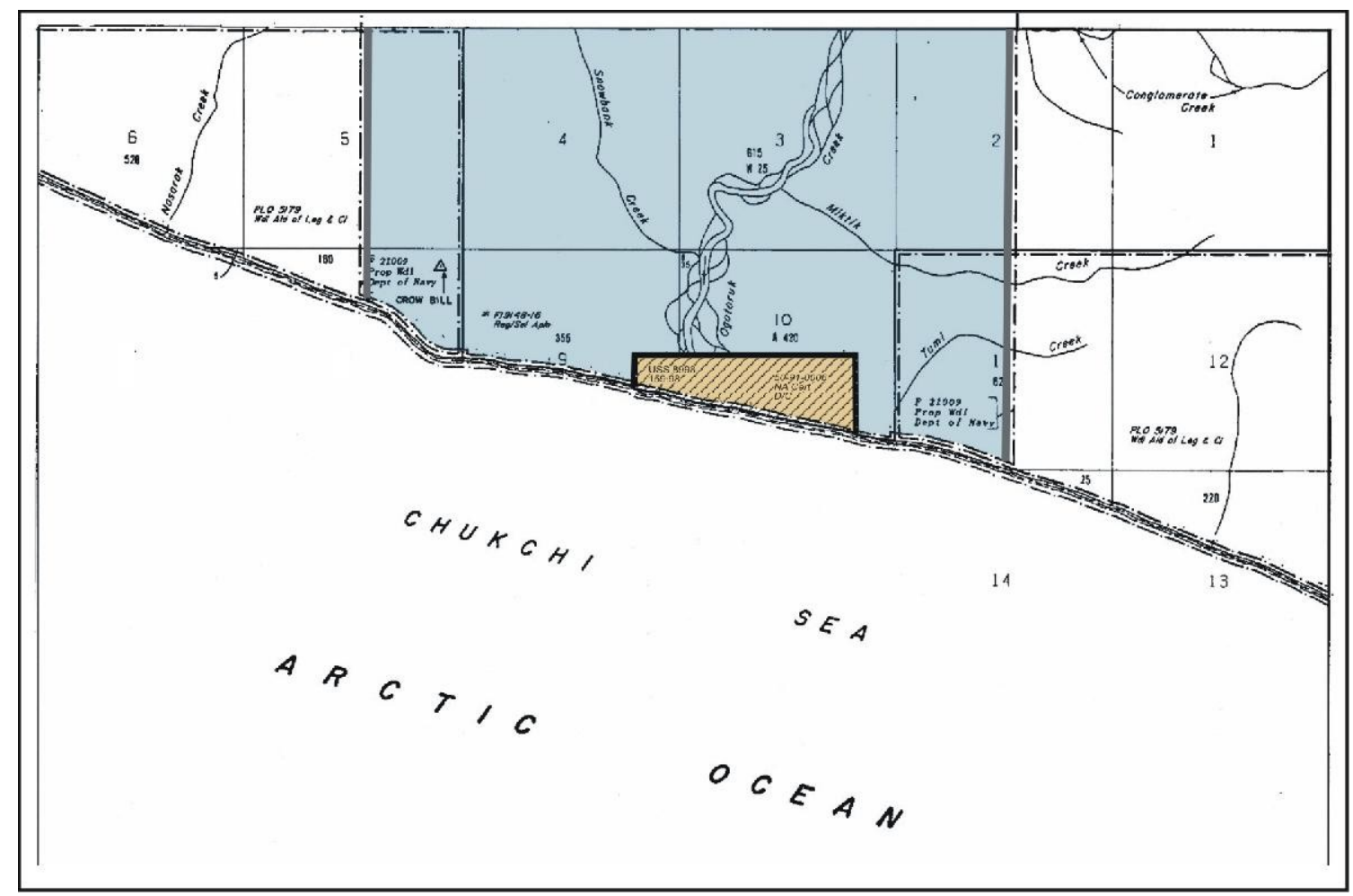

Figure 2-2. Portion of BLM-Alaska Record Title Plot Showing Navy-Administered Land (shaded in blue) and Patented Native American Allotment (cross hatch) at the Mouth of Ogotoruk Creek.

The land ownership and administration authorities have changed since Project Chariot was initiated. The following provides a summary of the land ownership and administration of the land areas once occupied by the Project Chariot sites.

The Federal Government owned all the land area used by Project Chariot and the support facilities. At the time of the project's initial inception in 1958, the land was administered by BLM. "On June 9, 1958, AEC submitted an application to BLM to withdraw the lands to 'conduct extensive environmental studies,' resulting in a Notice of Proposed Withdrawal that was published in the Federal Register 3 months later.' 
In 1962, the decision was made not to pursue the nuclear excavation project at the Project Chariot Site. The 1,024,000-acre $\left(4,144 \mathrm{~km}^{2}\right)$ land withdrawal request was no longer needed by AEC.

In December 1966, the U.S. Navy assumed administration of all AEC improvements in the Ogotoruk Valley and obtained a BLM Special Land Use Permit (SLUP), effective for 5 years, resulting in 4,700 acres $\left(19.0 \mathrm{~km}^{2}\right)$ becoming the Cape Thompson Naval Site. The site was used as a logistical support base for the Naval Arctic Research Laboratory. The U.S. Navy maintained the buildings at the former Project Chariot base camp and used them as living quarters, shops, garages, and generator facilities. The three airstrips were also re-worked and improved. When the SLUP expired in December 1970, the Project Chariot Site fell into intermittent use status.

In March 1972, Public Land Order 5179 (Federal Register 1972) withdrew the entire township containing the Project Chariot base camp, subject to "valid existing rights" concerning addition to, or creation of, units of a National Park, Forest, or Wildlife Refuge. One month later, a Native American allotment application for 160 acres $\left(0.65 \mathrm{~km}^{2}\right)$ surrounding the Project Chariot base camp, including most of the airstrips, was formally filed.

Two years later, the Navy filed an application for withdrawal of the 4,700 acres located within their former SLUP.

On December 2, 1980, the Alaska National Interest Land Claims Act was passed, and the Ogotoruk Valley was included in an area designated the Cape Thompson Subunit of the Chukchi Sea Unit of the AMNWR (Federal Register 1980) ${ }^{1}$. USFWS would now have jurisdiction over much of the old Project Chariot lands, although the U.S. Navy application for withdrawal of the lands, the Artic Slope Regional Corporation land selection, and the Native American allotment application were still valid and remained active.

The Native American allotment claim for the Project Chariot Site-base camp and most of landing strips-was approved in January 1987, and the claim was subsequently surveyed (BLM 1990). The patent was issued in 1990; easements were reserved to the United States for a trail along the beach through the allotment, a trail from the beach to the main camp and its airstrip, and the long runway on the eastern portion of the allotment.

The U.S. Navy is the administrator of the land on which the tracer tests and subsequent remediation was done in 1993. The Project Chariot Site resides on the patented Native American allotment (Figure 2-2).

${ }^{1}$ Public Land Order (PLO) 5710 was deleted and replaced by PLO 5179 (Federal Register 1972). 


\subsection{Access to the Project Chariot Area}

The Project Chariot tracer-test plots are located in a remote and isolated area in the Ogotoruk Valley near the confluence of the Ogotoruk and Snowbank Creeks and upstream along Snowbank Creek. The region is approximately 200 miles $(321.9 \mathrm{~km})$ north of the Arctic Circle and is bounded on the southwest by the Chukchi Sea. Extreme weather conditions make the site inaccessible for 10 months of the year. The closest populated areas are Point Hope (population 639), which is 32 miles $(51.5 \mathrm{~km})$ northwest of the Project Chariot sites, and Kivalina (population 317), which is 41 miles $(66.0 \mathrm{~km})$ to the southeast (see Figure 1-1). Access to the former tracer-test site is limited to air or water transportation (DOE 1994).

Access to the tracer-test area is through the patented Native American allotment. Although the Federal Government has easements on the allotment so it can reach the tracer test sites by land, access via the airstrips or the beach requires the permission of the allotment holder. Because the AMNWR withdrawal excludes navigable waters (i.e., waters below the high-water line), USFWS has no access jurisdiction.

The Project Chariot tracer-test sites have been clean closed. There are no restrictions to this land area as a result of the tracer-test study conducted in 1962 and clean closure in 1993. Because the airstrips and beach access occupy land held under a patented Native American allotment, permission must be obtained from the allotment holder prior to use of these facilities.

\subsection{Public Participation}

Public meetings were held in Washington, DC, and cities in Alaska. No other formal public participation is planned. DOE-LM will post key documents on its website and will respond to public inquiries.

Inquiries may be addressed to:

U.S. Department of Energy

Office of Legacy Management; Land and Site Management

ATTN: Project Chariot, Alaska

2597 B 3/4 Road

Grand Junction, CO 81503

Phone: $970-248-6000$

Fax: 970-248-6040

Internet URL: www.lm.doe.gov

Email: $\underline{\operatorname{lm} . r e c o r d s @ g j o . d o e . g o v}$

This document is from 2005. For current contact information, please contact the Office of Legacy Management at http://www.LM.doe.gov/cotnact.htm 


\subsection{Records Management}

The DOE Nevada Site Office Environmental Management Program (NSO EM) contractor has approximately $30 \mathrm{ft}^{3}\left(0.85 \mathrm{~m}^{3}\right)$ of record material for Project Chariot. The records are located in its Central File, the Technical Library, and an off-site inactive records storage facility. The DOE National Nuclear Security Administration (NNSA)/NSO EM has a total of about $10 \mathrm{ft}^{3}\left(0.28 \mathrm{~m}^{3}\right)$ of records maintained in its office; inactive records for this site are stored at its records center in Las Vegas, Nevada.

NNSA will be responsible for records pertaining to former employees or health and safety issues associated with former site operations. The Project Chariot records currently in the custody of NSO EM and its contractor will be transferred to DOE-LM in Grand Junction, Colorado. These records contain information needed to ensure the continued management and any follow-on actions and controls required to protect public health and the environment and to demonstrate compliance with applicable legal requirements.

Project Chariot records will be maintained by DOE-LM in full compliance with all federal records management requirements, including:

- $\quad$ Title 44 United States Code

Chapter 29, "Records Management by the Archivist of the United States and by the Administrator of General Services,"

Chapter 31, "Records Management by Federal Agencies," and

Chapter 33, "Disposal of Records."

- Title 36 Code of Federal Regulations (CFR) Parts 1220-1238, "National Archives and Records Administration"

This records management plan will follow the current quality assurance program plan for longterm surveillance and maintenance and future updates (DOE 2003).

\subsection{Access and Retrieval}

In accordance with the provisions of the Freedom of Information Act, the records retained by DOE-LM for the Project Chariot activities will be available to the allotment holder and to stakeholders. A limited number of key documents will be made available electronically on the DOE-LM Internet website. In addition, DOE-LM will place copies of selected documents about the site at local and regional Alaska libraries.

\subsection{Disposition of the Record Collection}

The National Archives and Records Administration Regional Records Center in Denver, Colorado, is the designated facility for archived Project Chariot records. DOE-LM will retain custody of the records sent to that facility and will be responsible for their destruction when no longer needed. All records with permanent value will be transferred to and will be the responsibility of the National Archives and Records Administration, Rocky Mountain Region, in 
Denver, Colorado. DOE has established records disposition schedules that provide the authority for the transfer or disposal of records created and maintained by this agency.

\subsection{Site Maps}

The maps for the Project Chariot sites show the locations of the property boundaries, roads inside and near the property boundaries, and section, township, range, and principal meridian designations. Map data are maintained in a geographical information system database.

\subsection{Site Record Drawings and Maps}

Site record drawings and maps represent final site conditions. These drawings and maps are included in the remedial action report (DOE 1994) and will be managed in the permanent Project Chariot records file at the DOE-LM Grand Junction office.

\subsection{Site Photographs and Other Special Media}

Historical photographs and other special media created during various phases of Project Chariot, the tracer-test site remediation, and final site conditions will be maintained in the Project Chariot records file. These media provide a visual record to complement the as-built drawings and maps.

\subsection{Site Aerial Photographs}

Aerial photographs of the Project Chariot tracer-test site were taken numerous times during operation and reclamation of the site. The photographs provide a record for monitoring changing conditions (e.g., erosion, vegetation, and land use) over time and will be preserved by DOE-LM in the permanent records.

\subsection{References}

BLM (Bureau of Land Management), 1974. U.S. Department of Interior. Alaska Land Information System, Historical Index Retrieved by Meridian, Township and Range: 44, 31N, 31W, Case Number F 21009, March 18.

BLM (Bureau of Land Management), 1990. U.S. Department of Interior. Alaska Land Information System, Historical Index Retrieved by Meridian, Township and Range: 44, 31N, 31W, Allotment number: 50-91-0006, Survey number USS 8998, October 19.

CFR (Code of Federal Regulations), 1997. Title 36 CFR Parts 1220-1238, "National Archives and Records Administration," U.S. Government Printing Office, Washington, DC.

Fiore, J. N., 1992. U.S. Department of Energy Nevada Operations Office, letter to R.C. Amick, Chief Counsel, Office of Chief Counsel, U.S. Department of Energy Nevada Operations Office, entitled "Project Chariot, Alaska: Request for Assistance," November 5, Las Vegas, Nevada.

DOE (U.S. Department of Energy), 1993. Project Chariot: 1962 Tracer Study Site Assessment and Remedial Action Plan, 93-294, Draft, Nevada Operations Office, Las Vegas, Nevada. 
DOE (U.S. Department of Energy), 1994. Project Chariot Site Assessment and Remedial Action Final Report, DOE/NV-368, Nevada Operations Office, Las Vegas, Nevada.

DOE (U.S. Department of Energy), 2003. Quality Assurance Program Plan for the Long-Term Surveillance and Maintenance Program, GJO-2003-435-TAC, Office of Legacy Management, Grand Junction, Colorado.

DOE (U.S. Department of Energy), 2004. Project Chariot: Transition Plan, Draft Final, DOE/NV - XXX, National Nuclear Security Administration, Nevada Site Office, Las Vegas, Nevada, July.

Federal Register, 1972. Public Land Order 5179, "Alaska; withdrawing lands in and of legislation concerning... creation of...the National park, Forest, Wildlife Refuge..." as amended, 37 FR 5579, March 16.

Federal Register, 1980. Public Land Order 5710, “Alaska; withdrawing for Alaska Maritime National Wildlife Refuge," 45 FR 9704, February 11.

United States Code, 1969. Title 44, "Public Printing and Documents," Chapter 29, "Records Management by the Archivist of the United States and by the Administrator of General Services"; Chapter 31, "Records Management by Federal Agencies"; and Chapter 33, "Disposal of Records"; U.S. Government Printing Office, Washington, DC.

USGS (United States Geological Survey), 1960. Point Hope [AK] Quad Map, Scale 1:63360, 1960. Download from Topozone.com.

USFWS (U.S. Department of Interior, Fish and Wildlife Service), 1993a. Cape Thompson Subunit map, May 1.

Vandegraft, D.L. (Cartographic Unit, Division of Realty, U.S. Fish \& Wildlife Service), 1993. "Project Chariot: Nuclear Legacy of Cape Thompson," in Proceedings of the U.S. Interagency Arctic Research Policy Committee Workshop on Arctic Contamination, Anchorage, Alaska, May 6. 
Appendix A

Alaska Department of Environmental Conservation

Closure Approval Letters 
$\because$ a

DEPT. OF ENVIRONMENTAL CONSERVATION
WALTER J. HICKEL, GOVERNOR

Telephone: (907) 451-2360

Fax: (907) 451-2187

NRO File: 475.25 .001

Northern Regional Office

1001 Noble Street, Suite 350, Fairbanks, AK 99701-4980

August 23, 1993

Mr. Kevin Cabble

DOE Nevada Operations Office

Environmental Restoration Division, ERD

P.O. Box 98518

Las Vegas, NV 89193-8518

Dear Mr. Cabble:

RE: Closure of Project Chariot Soil Disposal Mound

The Department has reviewed the results of the soil disposal mound post-excavation sampling. Results of the sampling indicate that the cleanup level of less than $10 \mathrm{pCi} / \mathrm{g}$ has been achieved. Based on sampling results and our field team's observations, the Department approves the closure of the soil disposal mound.

If you have any questions, please give me a call at 907-451-2172.

Sincerely,

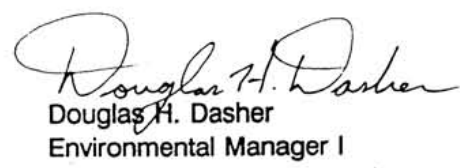

DHD/jg h:|eq|capet|closur.mou

cc: Aikens, J. - NSB

Greene, C. - NAB

Hawley, R. - Kivalina

Koonuk, R. - Pt. Hope

McGee, P. - ADEC/NRO

Schaefer, J. - Pt. Hope

Stone, D. - Pt. Hope 


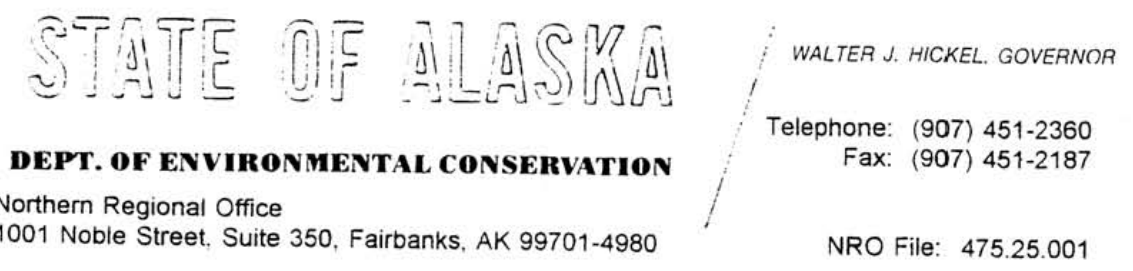

August 26, 1993

Mr. Kevin Cabble

DOE Nevada Operations Office

Environmental Restoration Division, ERD

P.O. Box 98518

Las Vegas, NV 89193-8518

Dear Mr. Cabble:

RE: Closure of Project Chariot cesium 137 plot

The Department has reviewed the results of the cesium 137 plot post-excavation

sampling. Results of the sampling indicate that the cleanup level of less than $10 \mathrm{pCi} / \mathrm{g}$

has been achieved. Based on sampling results and our field team's observations, the

Department approves the closure of the cesium 137 plot.

If you have any questions, please give me a call at 907-451-2172.

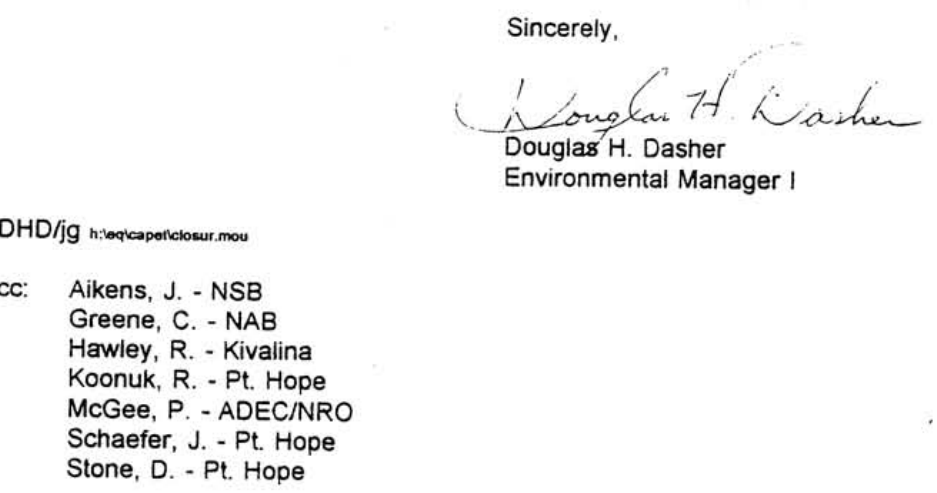


Appendix B

Recipients of this Plan 


\section{Anchorage, Alaska}

Mr. John Halverson

State of Alaska

Department of Environmental Conservation

555 Cordova Street

Anchorage, AK 99501

Mr. Jeff J. Nelson

NANA Development Corporation

1001 East Benson Blvd.

Anchorage, AK 99508

Mr. Andy Schell

Chief Operating Officer

Tikigaq Corporation

2121 Abbott Road

Anchorage, AK 99507

Arctic Slope Regional Corporation

3900 C Street, Suite 801

Anchorage, AK 99503-5963

\section{Barrow, Alaska}

Mr. Richard Savik Glenn

Vice President of Land

Artic Slope Regional Corporation

P.O. Box 129

Barrow, AK 99723

North Slope Borough

Office of the Mayor

P.O. Box 69

Barrow, AK 99723

Tuzzy Consortium Library

Ilisagvik College

P.O. Box 749

5421 N. Star Street

Barrow, AK 99723

\section{Fairbanks, Alaska}

Mr. Douglas H. Dasher

Environmental Manager, Department of

Environmental Conservation

Northern Regional Office, State of Alaska

1001 Noble Street Suite 350

Fairbanks, AK 99701-4980

The Honorable Lisa Murkowski

U.S. Senate

Federal Building

101 12th Avenue Room 216

Fairbanks, AK 99701

The Honorable Ted Stevens

U.S. Senate

Federal Building

101 12th Avenue Room 206, Box 4

Fairbanks, AK 99701

The Honorable Don Young

U.S. House of Representatives

Off1ice of Congressman Don Young

101 12th Avenue, \# 10

Fairbanks, AK 99701-1954

Fairbanks North Star Borough

Public Library and Regional Center

1215 Cowles Street

Fairbanks, AK 99701

U.S. Bureau of Land Management

Northern Field Office

1150 University Avenue

Fairbanks, AK 99709-3844

University of Alaska, Fairbanks

Elmer E. Rasmuson Library

310 Tanana Drive

Fairbanks, AK 99775-6817 


\section{Homer, Alaska}

Mr. Dave Roseneau

U.S. Fish \& Wildlife Service

Alaska Maritime National Wildlife Refuge

95 Sterling Highway, Suite 1

Homer, AK 99603-7473

\section{Juneau, Alaska}

The Honorable Richard Foster

Alaska House of Representatives

State Capital, Room 410

Juneau, AK 99801-1182

The Honorable Reggie Joule

Alaska House of Representatives

State Capital, Room 405

Juneau, AK 99801-1182

The Honorable

Frank H. Murkowski

Governor of Alaska

Office of the Governor

P.O. Box 110001

Juneau, AK 99811

The Honorable Donald Olson

The State Senate, Alaska

State Capital, Room 510

Juneau, AK 99801-1182

\section{Kotzebue, Alaska}

Mr. Jim Dau

Division of Subsistance

Alaska Department of Fish \& Game

Nordlum Office Bldg.

P.O. Box 689

240 5th Avenue

Kotzebue, AK 99752-0689

Mr. Frank Greene

Vice President, Land

NANA Regional Corporation

P.O. Box 49

Kotzebue, AK 99752
Mr. Wilfred W. Lane

P.O. Box 176

Kotzebue, AK 99752-0176

Chukchi Consortium Library

College of Rural Alaska

Chukchi Campus

P.O. Box 297

Kotzebue, AK 99752-0297

\section{Point Hope, Alaska}

Mr. Earl Kingik

Wildlife and Parks Director

Point Hope IRA Council

P.O. Box 109

Point Hope, AK 99766

Mr. Ernie Frankson

Point Hope IRA Council

P.O. Box 109

Point Hope, AK 99766

Mr. Rex A Rock Sr.

President

Tikigaq Corporation

P.O. Box 9

Point Hope, AK 99766

Mr. Jack Schaefer

Tikigaq Corporation

P.O. Box 9

Point Hope, AK 99766

City of Point Hope

P.O. Box 169

Point Hope, AK 99766

Poulsbo, Washington

Mr. Mike Brady

U.S. Navy, Naval Facilities Engineering

Command

Engineering Field Activity, Northwest

Real Estate Group

19917 7th Avenue, NE

Poulsbo, WA 98370 